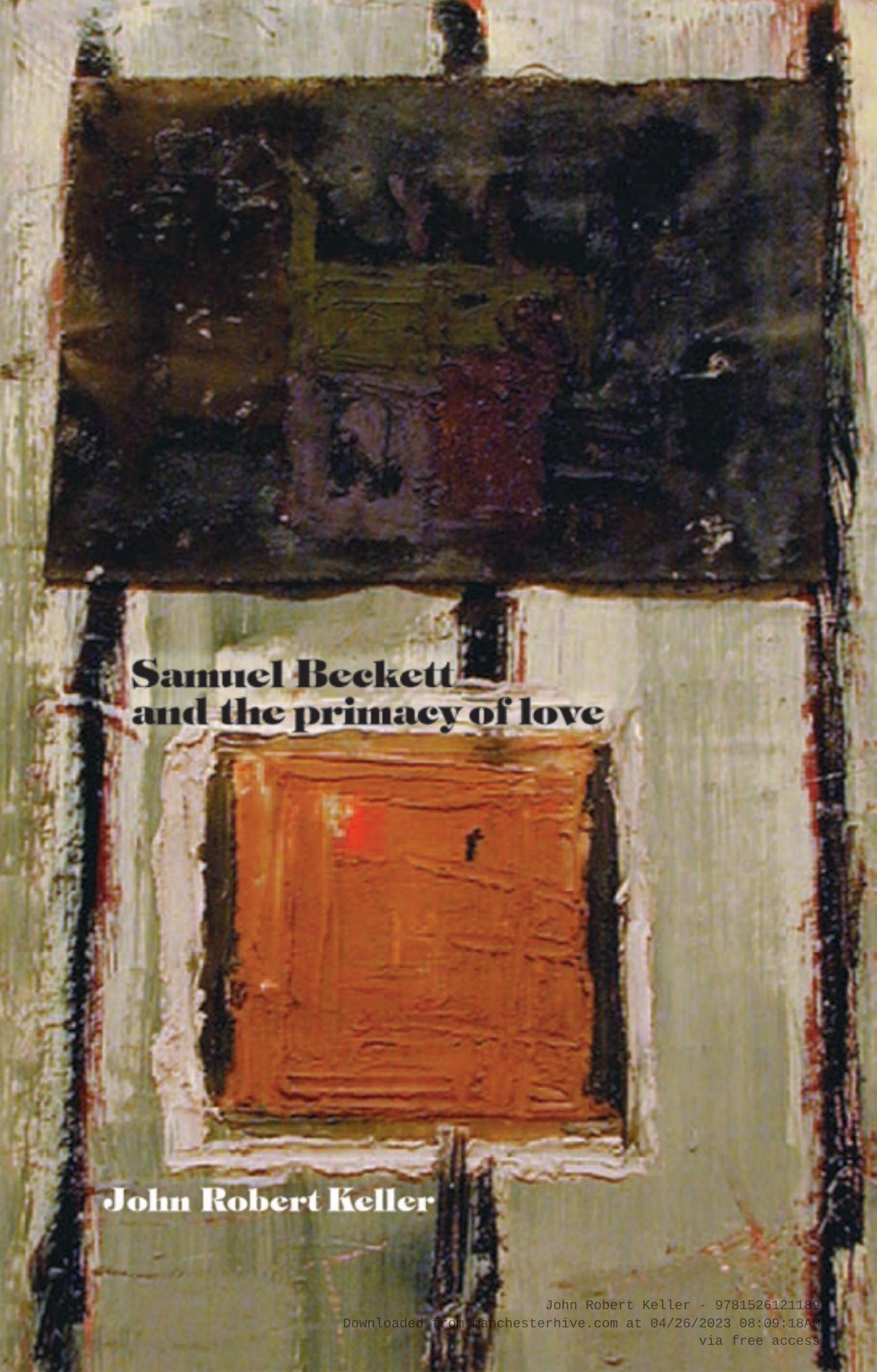


Samuel Beckett and the primacy of love

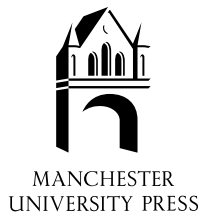


John Robert Keller - 9781526121189 Downloaded from manchesterhive.com at 04/26/2023 08:09:18AM 


\title{
Samuel Beckett and the primacy of love
}

\author{
JOHN ROBERT KELLER
}

\section{Manchester University Press}

Manchester and New York

distributed exclusively in the USA by Palgrave 


\title{
Copyright (C) John Robert Keller 2002
}

The right of John Robert Keller to be identified as the author of this work has been asserted by him in accordance with the Copyright,

Designs and Patents Act 1988

\author{
Published by Manchester University Press \\ Oxford Road, Manchester M13 9NR, UK \\ and Room 400, 175 Fifth Avenue, New York, NY 10010, USA \\ www.manchesteruniversitypress.co.uk \\ Distributed exclusively in the USA by \\ Palgrave, 175 Fifth Avenue, New York, NY 10010, USA \\ Distributed exclusively in Canada by \\ UBC Press, University of British Columbia, 2029 West Mall, \\ Vancouver, BC, Canada V6T 1Z2 \\ British Library Cataloguing-in-Publication Data \\ A catalogue record for this book is available from the British Library \\ Library of Congress Cataloging-in-Publication Data applied for
}

ISBN 0719063124 hardback
0719063132 paperback

First published 2002

$\begin{array}{lllllllllllllllllll}10 & 09 & 08 & 07 & 06 & 05 & 04 & 03 & 02 & 10 & 9 & 8 & 7 & 6 & 5 & 4 & 3 & 2 & 1\end{array}$

Typeset in Dante with Tiffany display

by Koinonia Ltd, Manchester

Printed in Great Britain

by Bell $\&$ Bain Ltd, Glasgow 